\section{Infrared drying as a potential alternative to convective drying for biltong production}

\author{
Kipchumba Cherono, ${ }^{1}$ Gikuru Mwithiga, \\ Stefan Schmidt ${ }^{2}$ \\ 'Bioresources Engineering Research \\ Group, University of KwaZulu-Natal, \\ Pietermaritzburg; 2Department of \\ Microbiology, University of KwaZulu- \\ Natal, Pietermaritzburg, South Africa
}

\begin{abstract}
Two infrared systems set at an intensity of $4777 \mathrm{~W} / \mathrm{m}^{2}$ with peak emission wavelengths of 2.5 and $3.5 \mu \mathrm{m}$ were used to produce biltong by drying differently pre-treated meat. In addition to meat texture and colour, the microbial quality of the biltong produced was assessed by quantifying viable heterotrophic microorganisms using a most probable number (MPN) method and by verifying the presence of presumptive Escherichia coli in samples produced using infrared and conventional convective drying. The two infrared drying systems reduced the heterotrophic microbial burden from $5.11 \log _{10}$ MPN/g to $2.89 \log _{10}$ MPN/g (2.5 $\mu \mathrm{m})$ and $3.42 \log _{10} \mathrm{MPN} / \mathrm{g}(3.5 \mu \mathrm{m})$, respectively. The infrared systems achieved an up to one $\log$ higher MPN/g reduction than the convective system. In biltong samples produced by short wavelength $(2.5 \mu \mathrm{m})$ infrared drying, $E$. coli was not detectable. This study demonstrates that the use of short wavelength infrared drying is a potential alternative to conventional convective drying by improving the microbiological quality of biltong products while at the same time delivering products of satisfactory quality.
\end{abstract}

\section{Introduction}

The drying of meat is one of the first important food preservation inventions of prehistoric humankind (Campbell-Platt, 1995). Drying causes chemical, microbial and enzymatic changes in meat products that are responsible for the extension of their shelf life. Coupled with drying, spicing and salting give special flavours to the dried meats that make them taste better, thus improving palatability, lengthening their shelf life and yielding products of improved quality (Norman and Corte, 1985). The reduction of water content and water activity inhibits microbial growth by introducing unfavourable conditions. Spicing and salting introduces further hurdles for microbial growth in the products (Heinz and
Hautzinger, 2010). In addition, meat drying inhibits enzymatic and oxidative spoilage (Dave and Ghaly, 2011).

Different dried meat products exist across different nations in the world. Some of the dried ready-to-eat (RTE) meat products produced across the world include: Brazilian Charque, Ethiopian Qwanta, American Jerky, Canadian Pemmican and Tunisian Kaddid (Heinz and Hautzinger, 2010; Norman and Corte, 1985; Naidoo and Lindsay, 2010a, 2010b). Biltong is a popular meat-based RTE snack widely consumed in South Africa, which is commonly described in the country as a national delicacy (Naidoo and Lindsay, 2010b). Although limited information is available about the size of the South African biltong market, it was estimated that at least 100 tons of biltong were produced annually by 1984 (Osterhoff and Leistner, 1984). Attwell (2003) depicted a rapid rise in the number of biltong plants being set up in South Africa.

Biltong is generally prepared from meat of freshly killed herbivores by cutting the loin region lengthwise, generating meat slices varying from 1 to 2 feet in length with a maximum width of 2 inches (Nortjé et al., 2005). Sliced meat strips can be salted using coarse salt (1-2 kg per $50 \mathrm{~kg}$ meat) and spiced with numerous ingredients such as pepper, garlic, sugar, coriander or aniseed, to meet the taste preferences of consumers (Heinz et al., 1990). Biltong is usually dried outside in ambient conditions under a shade to protect it from rain, frost or dew for 10-14 days. After drying, biltong is ready for consumption or storage for several months (Heinz et al., 1990; Heinz and Hautzinger, 2010). Only a limited number of studies have established the efficacy of a combination of different processing methods on the microbial quality of biltong. A study by Nortjé et al. (2005) showed that the conventional hot air drying method is not sufficient to achieve the recommended microbial log reduction in dried biltong, which is essential to establish the required hygiene status and to improve the product's shelf-stability.

Consumers are potentially put at risk when eating biltong not meeting hygiene standards due to faecal contamination and the presence of pathogens (Bokkenheuser, 1963; Botes, 1966). A recent study by Petit et al. (2014) revealed that the total plate counts per $\mathrm{g}$ of certain commercial biltong products with high moisture content from South Africa reached unacceptably high levels of up to $10^{9}$ colony forming units (CFU) per g.

Infrared radiation, the portion of the electromagnetic spectrum with an output wavelength range between 0.75 and $1000 \mu \mathrm{m}$ produced by any object above the temperature of absolute zero (Krishnamurthy et al., 2008), can be used to dry food and agricultural products. Hamanaka et al. (2006) used infrared emitters
Correspondence: Kipchumba Cherono, Bioresources Engineering Research Group, School of Engineering, University of KwaZuluNatal, 3209 Pietermaritzburg, South Africa. Tel: +27.729066869 - Fax: +27.332605818 . E-mail: kip.cherono@gmail.com

Key words: Biltong; Hygiene; Infrared drying; Meat texture; Microbiological quality.

Funding: this study was funded by the research office of the University of KwaZulu-Natal (KC, GM) and the National Research Foundation (SS).

Conflict of interest: the authors declare no potential conflict of interest.

Received for publication: 13 November 2015. Revision received: 21 April 2016.

Accepted for publication: 23 April 2016.

This work is licensed under a Creative Commons Attribution-NonCommercial 4.0 International License (CC BY-NC 4.0).

(C) Copyright K. Cherono et al., 2016

Licensee PAGEPress, Italy

Italian Journal of Food Safety 2016; 5:5625

doi:10.4081/ijfs.2016.5625

of different wavelengths to inactivate bacterial spores, concluding that the inactivation of these spores depends on the water activity of the product, and that emitters using shorter wavelengths are more effective in inactivating bacterial endospores than those using a longer wavelength.

Infrared drying systems have therefore microbial decontamination potential that can improve the microbial quality and in turn the hygiene status of biltong. Several studies on the processing and the resulting quality of biltong are available, but none has attempted to generate biltong using infrared meat drying systems. The objective of this study was therefore to investigate the applicability of infrared heating at different peak emission wavelengths for the production of biltong.

\section{Materials and Methods}

\section{Sample preparation}

Beef samples were procured from a local supermarket butchery (Pietermaritzburg, South Africa). They consisted of cuts from the loin region of a slaughtered beef carcass and were sliced along the muscle fibres to dimensions of $150 \times 25 \mathrm{~mm}$ at a thickness of either 5 , 10 or $15 \mathrm{~mm}$ using a commercial meat slicer (model 610; Hobart Corp., Troy, OH, USA) under aseptic conditions. Upon slicing, the samples were packed in sterile polyethylene 
bags, heat sealed (Kenpak heat sealer; Fisher Scientific, Waltham, MA, USA) and transported to the laboratory within an hour after packaging, where they were refrigerated at $4^{\circ} \mathrm{C}$ before the commencement of the marinating process.

Approximately $500 \mathrm{~g}$ of sliced beef was marinated for 6,12 and $24 \mathrm{~h}$ in salt $(12.6 \% \mathrm{w} / \mathrm{w})$ and spice marinade. The marinade was prepared in sterile containers using autoclaved warm demineralised water and a commercial spice formulation (Nice 'n Spicy; Biltongmakers, Cape Town, South Africa) at a concentration of $14 \%$ spice formulation w/w as recommended (Heinz et al., 1990). The moisture content of the beef samples was determined before and at the end of the marinating process using the AOAC 950.46 standard method (AOAC, 2000).

\section{Drying experiments}

Each of the three $500 \mathrm{~g}$ marinated beef slice batches $(6,12$ and $24 \mathrm{~h})$, was dried at a temperature of $25 \pm 1^{\circ} \mathrm{C}$ in a mechanical oven (Prolab, Johannesburg, South Africa) to a moisture content of $20 \pm 1 \%$ wet basis (wb), which is the typical moisture content of commercial biltong. Drying runs were repeated three times for each marinating treatment. This process was repeated by drying the samples using either a short wavelength (SW) infrared heater (peak emission wavelength=2.5 $\mu \mathrm{m}, \quad \mathrm{QC}-121240$; Omega, Manchester, UK), or a long wavelength (LW) infrared heater (peak emission wavelength=3.5 $\mu \mathrm{m}$, QF-121210; Omega). Both infrared heaters were set to deliver the same infrared intensity of $4777 \mathrm{~W} / \mathrm{m}^{2}$ at the product's surface. The temperature of all meat samples analysed was monitored using K-type thermocouples (TT-K-24-25; Omega) and logged automatically using a data logger (OM-DAQ-USB2401; Omega). When the samples reached the target moisture level of $20 \pm 1 \% \mathrm{wb}$, which was typically reached after $191.4 \pm 57.6,35.1 \pm 8.6$ and $10.4 \pm 3.3 \mathrm{~h}$, for the convective, LW and SW drying systems, respectively, drying was stopped and the dried samples were stored in sterile polyethylene Ziploc bags (Victoria Packaging, Pietermaritzburg, South Africa) prior to analysing meat colour, texture and microbiological quality.

\section{Assessment of meat colour and texture}

The colour of the dried product was measured relative to the marinated product using a Hunterlab colorimeter (Colourflex EZ; Hunterlab, Reston VA, USA), with an instrument port size of $60 \mathrm{~mm}$ and an aperture size of $31.5 \mathrm{~mm}$ (1.26 inches). The instrument was calibrated using black and white standardisation tiles. The samples were prepared according to the American Meat Science Association guidelines (AMSA, 2012), then the lightness $\left(\mathrm{L}^{*}\right)$, redness $\left(\mathrm{a}^{*}\right)$ and yellowness $\left(\mathrm{b}^{*}\right)$ values were measured using Illuminant $A$ at an observation angle of $10^{\circ}$ as recommended (AMSA, 2012). For each sample, readings were replicated thrice. Texture profile was measured using a texture analyser (TA.XT plus; Stable Micro Systems, Godalming, UK) with a load cell capacity of $30 \mathrm{~kg}$. The test was conducted at a crosshead speed of $5 \mathrm{~mm} / \mathrm{sec}$ using a rectangular Warner Bratzler probe. Samples were deformed to $50 \%$ of their original thickness in two successive bites with no rest time between the bites. Each sample was tested three times by changing the deformation points in a way that the sample was first divided into three equal parts, then their approximate centres were marked and used as deformation points. Force deformation curves were generated using Exponent ${ }^{\circledR}$ software (Stable Micro Systems), yielding information on product hardness, gumminess, cohesiveness, resilience, chewiness and springiness.

\section{Quantification of heterotrophic microorganisms}

The most probable number (MPN) of heterotrophic microorganisms per $g$ of food material was established using an MPN standard procedure (Health Canada, 2002), but instead of selective media, standard 1 nutrient broth (Merck, Darmstadt, Germany) was used for the quantification of heterotrophic microorganisms. A representative $10 \mathrm{~g}$ sample of the material to be analysed (sliced fresh beef, biltong spice, $6 / 12$ and $24 \mathrm{~h}$ marinated beef, convective/LW and SW dried meat) was obtained by aseptically cutting off pieces of biltong from its respective batch. Its mass was measured using an electric balance by putting it in a preweighed, autoclaved $\left(20 \mathrm{~min}\right.$ at $\left.121^{\circ} \mathrm{C}\right)$ Erlenmeyer flask. Sterile peptone water (containing $1 \mathrm{~g}$ peptone and $8.5 \mathrm{~g} \mathrm{NaCl}$ per L distilled water, $\mathrm{pH}=7$ ) was then added to the $10 \mathrm{~g}$ biltong sample in the flask to a total mass of $100 \mathrm{~g}$. This mixture was then homogenised in a sterilised food processor (FP120; Kenwood, Tokyo, Japan) for $2 \mathrm{~min}$ at $2500 \mathrm{rpm}$. This undiluted homogenate (the $10^{-1}$ dilution) was used to prepare subsequent decimal dilutions using sterile peptone water typically up to the $10^{-5}$ dilution. One mL samples of each serial decimal dilution was used to inoculate five parallel MPN tubes containing $5 \mathrm{~mL}$ sterile standard 1 nutrient broth (Merck). The MPN tubes were incubated in the dark in a temperaturecontrolled incubator (Heraeus BB 6220; Heraeus, Hanau, Germany) at $30 \pm 2{ }^{\circ} \mathrm{C}$ for $48 \mathrm{~h}$ to safeguard the detection of slow-growing heterotrophic microorganisms. Positive tubes showing growth were recorded after the incubation process. This procedure was also applied to the freshly sliced beef samples, the biltong spice and the marinated beef slices.
The MPN values were established as $\log _{10}$ MPN of viable heterotrophic microorganisms per gram of sample material with a $95 \%$ confidence interval established according to Garthright and Blodgett (2003).

\section{Detection of presumptive \\ Escherichia coli}

Each positive MPN tube generated in the MPN procedure for the quantification of heterotrophic microorganisms was thoroughly mixed and, by using a sterile inoculating loop, a sample was streaked onto Eosin Methylene Blue (EMB) agar (Merck) to verify the presence of presumptive Escherichia coli. The EMB plates were incubated for $24 \mathrm{~h}$ at a temperature of $37 \pm 2{ }^{\circ} \mathrm{C}$ in a temperature-controlled incubator (Heraeus BB 6220; Heraeus) and thereafter visually inspected for the presence of nucleated, dark colonies with a green metallic sheen that is indicative of the presence of $E$. coli (Leininger et al., 2001). E. coli ATCC8739 and Salmonella typhimurium ATCC14028 served as lactose positive and negative control.

\section{Statistical analysis}

All data were analysed using SPSS (Version 23; IBM, Armonk, NY, USA). One way ANOVA was used for all analyses at 0.05 significance level.

\section{Results}

The initial moisture content of beef slices of various thicknesses before marinating ranged from $75.33 \pm 0.43 \%$ wb for the $5 \mathrm{~mm}$ thick slices to $75.73 \pm 0.47 \%$ wb for the $15 \mathrm{~mm}$ thick slices (Figure 1).

The temperature of meat slices during the drying process employed to produce biltong varied with the marinating duration, thickness of slices and the systems used to dry the meat. Biltong produced using conventional drying was assumed to be at about the equipment setpoint temperature and is, therefore, not discussed in this section. Variations of average product temperature with marinating duration, product thickness and the infrared system used to dry meat samples to produce biltong are shown in Figure 2.

The average core temperature of meat samples dried under the LW infrared heater was $58.49^{\circ} \mathrm{C}$. It is evident that the average core temperature increased concomitant with meat slice thickness from 5 to $10 \mathrm{~mm}$, then decreasing with a further increase in product thickness, from 10 to $15 \mathrm{~mm}$ (Figure 2A). The marinating duration had a similar effect on the average core product temperature, which increased between 6 - to 12 -h marinating dura- 
tion and then decreased with a further increase in the marinating duration. Slices that were dried using the SW infrared heater (Figure 2B) showed core temperature decrease with increasing thickness, with the 5 mm thick samples having the highest average core temperature of between $86-93^{\circ} \mathrm{C}$. The average core temperature increased with an increase in marinating duration, with 24 -h marinated samples recording the highest average core temperature.

The product colour $\left(\mathrm{L}^{*} \mathrm{a}^{*} \mathrm{~b}^{*}\right)$ values and textural characteristics are shown in Table 1. These meat quality attributes were affected by both the drying system and the marinating process used, but were similar to a typical commercial biltong sample analysed in parallel.

The MPN values established for fresh beef, marinated beef, biltong spice and the dried biltong slices per $\mathrm{g}$ of material are shown in Table 2. The fresh beef slices had a $\log _{10} \mathrm{MPN} / \mathrm{g}$ of 5.11, thereby still meeting recommendations stipulated by Australian guidelines for raw beef (MSC, 2002) (Table 3), specifying an upper value $\mathrm{M}$ of $10^{6} \mathrm{CFU}$ per $\mathrm{g}$ for viable heterotrophic microorganisms. Similarly, it even met the satisfactory (m) quality thresholds

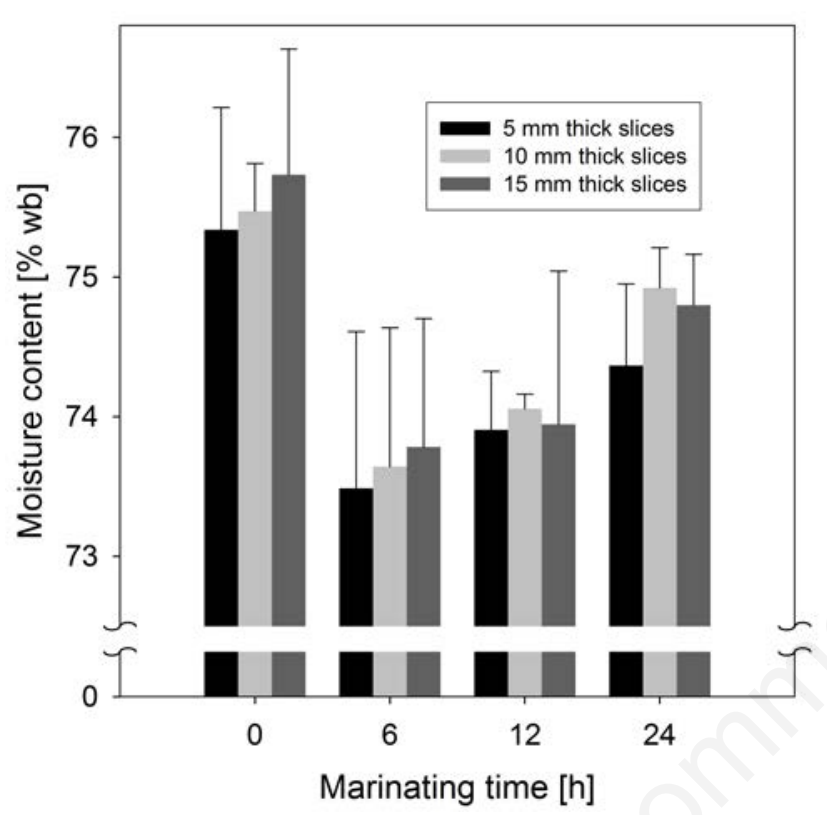

Figure 1. Changes over time in moisture content of biltong slices of various thicknesses that were marinated for 6, 12 and $24 \mathrm{~h}$.
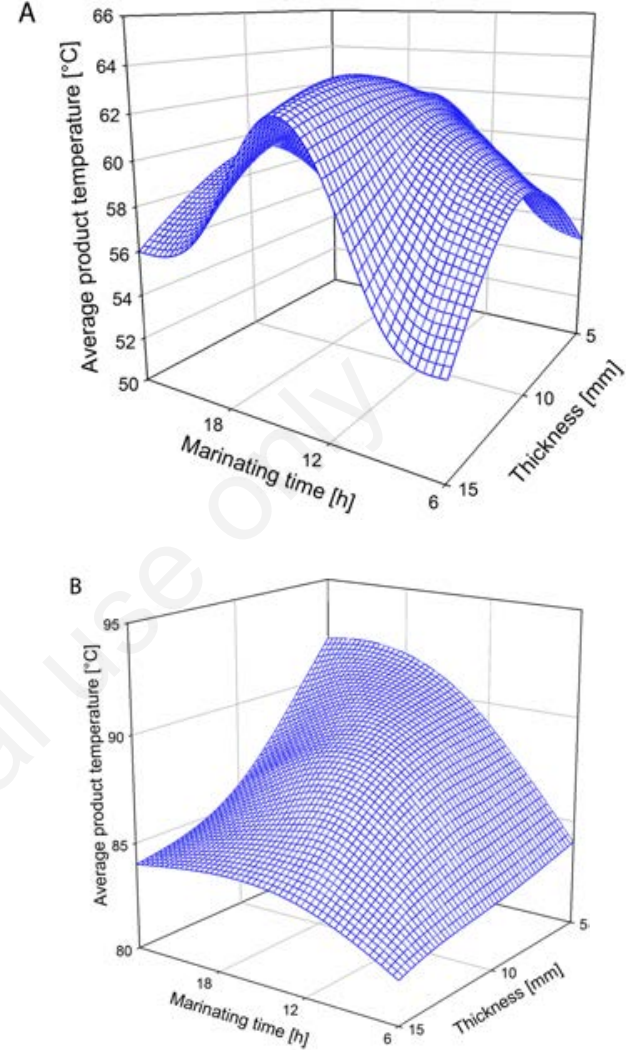

Figure 2. Three-dimensional representation of the variation of average product temperature with drying system, slice thickness and marinating duration of biltong samples. Samples were marinated for 6,12 and $24 \mathrm{~h}$ in a salt and spice marinade, then dried using a long (A) and a short wavelength (B) infrared heater.

Table 1. Colour and texture analysis of biltong produced using conventional and infrared drying at different marinating times compared with commercial biltong.

\begin{tabular}{|c|c|c|c|c|c|c|c|c|c|c|}
\hline \multirow[t]{2}{*}{ Drying system } & \multirow{2}{*}{$\begin{array}{l}\text { Marinating } \\
\text { time (h) }\end{array}$} & \multicolumn{3}{|c|}{ Colour parameters } & \multicolumn{3}{|c|}{ TPA parameters } & \multirow[b]{2}{*}{ Springiness } & \multirow[b]{2}{*}{ Resilience } & \multirow[b]{2}{*}{$\begin{array}{c}\text { Chewiness } \\
\text { (kgF) }\end{array}$} \\
\hline & & $L^{*}$ & $a^{*}$ & $b^{*}$ & $\begin{array}{l}\text { Hardness } \\
\text { (kgF) }\end{array}$ & Cohesiveness & $\begin{array}{l}\text { Gumminess } \\
(\mathrm{kgF})\end{array}$ & & & \\
\hline Convective & $\begin{array}{c}6 \\
12 \\
24\end{array}$ & $\begin{array}{l}27.50 \pm 0.70^{\mathrm{a}} \\
23.75 \pm 0.74^{\mathrm{b}} \\
26.07 \pm 0.84^{\mathrm{c}}\end{array}$ & $\begin{array}{c}8.63 \pm 1.21^{\mathrm{a}} \\
7.91 \pm 1.21 \mathrm{a}^{\mathrm{c}} \\
10.77 \pm 1.38 \mathrm{a}^{\mathrm{b}}\end{array}$ & $\begin{array}{l}11.07 \pm 1.15^{\mathrm{a}} \\
9.08 \pm 1.06 \mathrm{a}^{\mathrm{eh}} \\
13.79 \pm 1.22^{\mathrm{bc}}\end{array}$ & $\begin{array}{c}11.69 \pm 1.61 \mathrm{a} \\
14.87 \pm 1.47 \mathrm{a}^{\mathrm{c}} \\
24.05 \pm 1.41^{\mathrm{b}}\end{array}$ & $\begin{array}{l}0.51 \pm 0.04 a^{\text {cd }} \\
0.44 \pm 0.05^{\text {aff }} \\
0.39 \pm 0.05^{\text {abf }}\end{array}$ & $\begin{array}{l}5.87 \pm 0.32^{\mathrm{a}} \\
6.48 \pm 0.61^{\mathrm{a}} \\
9.45 \pm 0.24^{\mathrm{b}}\end{array}$ & $\begin{array}{c}0.97 \pm 0.04 \mathrm{a}^{\mathrm{bc}} \\
0.92 \pm 0.02^{\mathrm{abd}} \\
0.86 \pm 0.02^{\mathrm{de}}\end{array}$ & $\begin{array}{c}0.34 \pm 0.05^{\text {acfg }} \\
0.23 \pm 0.02^{\mathrm{b}} \\
0.31 \pm 0.01 \mathrm{a}^{\mathrm{cd}}\end{array}$ & $\begin{array}{l}5.43 \pm 1.36^{\mathrm{af}} \\
5.94 \pm 1.34^{\mathrm{a}} \\
8.10 \pm 1.42^{\mathrm{ab}}\end{array}$ \\
\hline LW & $\begin{array}{c}6 \\
12 \\
24 \\
\end{array}$ & $\begin{array}{c}25.42 \pm 0.90^{c} \\
21.89 \pm 1.01^{\mathrm{def}} \\
23.88 \pm 0.99^{\mathrm{d}}\end{array}$ & $\begin{array}{c}9.34 \pm 1.01^{\mathrm{a}} \\
6.36 \pm 0.94^{\mathrm{bc}} \\
7.82 \pm 1.01^{\mathrm{c}}\end{array}$ & $\begin{array}{c}12.62 \pm 0.95^{\mathrm{c}} \\
9.87 \pm 0.97^{\mathrm{i}} \\
10.27 \pm 1.13^{\text {ade }}\end{array}$ & $\begin{array}{l}16.82 \pm 1.12^{\mathrm{c}} \\
20.28 \pm 1.42^{\mathrm{d}} \\
23.32 \pm 1.70^{\mathrm{d}}\end{array}$ & $\begin{array}{c}0.53 \pm 0.06^{\mathrm{ce}} \\
0.55 \pm 0.07^{\text {ed }} \\
0.57 \pm 0.07 \mathrm{~g}\end{array}$ & $\begin{array}{c}8.56 \pm 0.69^{b} \\
10.86 \pm 0.30^{c} \\
12.81 \pm 0.55^{d}\end{array}$ & $\begin{array}{c}0.94 \pm 0.03^{\mathrm{abc}} \\
0.88 \pm 0.03^{\mathrm{df}} \\
0.82 \pm 0.03^{\mathrm{e}}\end{array}$ & $\begin{array}{l}0.27 \pm 0.03^{\mathrm{dc}} \\
0.36 \pm 0.06^{\mathrm{ef}} \\
0.38 \pm 0.02^{\mathrm{hg}}\end{array}$ & $\begin{array}{l}7.96 \pm 1.64^{\mathrm{ab}} \\
9.47 \pm 1.48^{\mathrm{bc}} \\
10.49 \pm 1.46^{\mathrm{c}}\end{array}$ \\
\hline SW & $\begin{array}{c}6 \\
12 \\
24\end{array}$ & $\begin{array}{c}21.58 \pm 0.83^{\text {eh }} \\
19.53 \pm 0.71^{\mathrm{g}} \\
20.83 \pm 0.79^{\mathrm{fgh}}\end{array}$ & $\begin{array}{l}8.77 \pm 0.79^{\mathrm{a}} \\
7.58 \pm 0.72^{\mathrm{a}} \\
8.89 \pm 0.78^{\mathrm{a}}\end{array}$ & $\begin{array}{l}9.47 \pm 1.00^{\text {afi }} \\
7.78 \pm 0.81^{\text {aj }} \\
8.02 \pm 0.77^{\mathrm{aj}}\end{array}$ & $\begin{array}{c}6.28 \pm 1.16^{\mathrm{e}} \\
8.33 \pm 0.98 \mathrm{e} \\
11.31 \pm 0.71^{\mathrm{f}}\end{array}$ & $\begin{array}{l}0.40 \pm 0.04^{\mathrm{f}} \\
0.39 \pm 0.05^{\mathrm{f}} \\
0.36 \pm 0.06^{\mathrm{f}}\end{array}$ & $\begin{array}{l}2.54 \pm 0.21^{\mathrm{e}} \\
3.35 \pm 0.18^{\mathrm{f}} \\
3.77 \pm 0.58^{\mathrm{f}}\end{array}$ & $\begin{array}{l}0.89 \pm 0.04^{\mathrm{f}} \\
0.83 \pm 0.02^{\mathrm{g}} \\
0.78 \pm 0.03^{\mathrm{g}}\end{array}$ & $\begin{array}{l}0.20 \pm 0.03^{\mathrm{i}} \\
0.18 \pm 0.03 \mathrm{i} \\
0.23 \pm 0.03 \mathrm{i}\end{array}$ & $\begin{array}{c}2.23 \pm 1.48^{\mathrm{eg}} \\
2.76 \pm 1.53^{\mathrm{f}} \\
2.91 \pm 1.58^{\mathrm{f}}\end{array}$ \\
\hline $\begin{array}{l}\text { Commercial biltong } \\
\text { sourced from local } \\
\text { supermarket }\end{array}$ & & $23.50 \pm 2.85$ & $8.36 \pm 2.85$ & $10.5 \pm 2.55$ & $29.55 \pm 3.13$ & $0.28 \pm 0.09$ & $7.55 \pm 0.88$ & $0.89 \pm 0.11$ & $0.29 \pm 0.16$ & $9.25 \pm 2.47$ \\
\hline
\end{tabular}

TPA, texture profile analysis; $\mathrm{L}^{*}$, lightness; $\mathrm{a}^{*}$, redness; $\mathrm{b}^{*}$, yellowness; $\mathrm{kgF}$, kilogram force; $\mathrm{LW}$, long wavelength; $\mathrm{SW}$, short wavelength. ${ }^{\text {ah }}$ Means in the same column with different letters indicate a significant difference (P 0.05 ). 
recommended for minced meat by the Deutsche Gesellschaft für Hygiene und Mikrobiologie (DGHM, 2012) and the European Union (European Commission, 2007). The fresh beef samples showed the presence of presumptive $E$. coli at $1.36 \log _{10}$ MPN per g, which is still acceptable based on recommendations for the limit value $M$ in raw beef and minced meat (Table 3 ) specified by the MSC (2002), the DGHM (2012) and the EU (2007).

The marinating process also controlled microbial growth as demonstrated by a clear reduction in the initial MPN/g value of 5.11 $\log _{10}$ for fresh beef to 3.14 for beef slices that had been marinated for $12 \mathrm{~h}$. An additional marinating from 12 to $24 \mathrm{~h}$ did not appear to provide an additional reduction in the microbial burden observed.

$E$. coli is a well-established hygiene indicator used to assess the presence of faecal contamination and the sanitary conditions during food preparation and processing (Reij and den Aantrekker, 2004). Presumptive E. coli colonies were not detected in biltong that was dried under the SW infrared heater and in the biltong spice. However, E. coli was detected in marinated beef samples but at a level of 0.89 $\log _{10} \mathrm{MPN} / \mathrm{g}$.

\section{Discussion}

\section{Product moisture content}

A limited number of studies report on the diffusion dynamics of water into the hydration sites of marinated meats as a function of their geometrical configurations (Yusop et al., 2010). Marination is a process that is driven primarily by the prevailing osmotic gradients of the process (Sams, 2000). A drop in the sample moisture content at the initial 0 - to 6 -h marinating interval is expected due to the diffusion of water out of the muscle tissue concomitant with the uptake of salt (a typical commercial biltong spice formulation contains approximately $90 \%$ salt) into the meat slices. This process will proceed to a point (in this case, close to the 6 -h marinating duration) where the osmotic equilibrium shifts due to the increase in water binding sites in the samples. The $15 \mathrm{~mm}$ thick samples are expected to record the highest moisture content, due to a higher relative proportion of myofibrils that constitute the primary hydration sites in marinated meat products (Yusop et al., 2010). In general, the marinating duration and the product thickness had no significant $(P \geq 0.05)$ effect on the moisture content of the marinated beef samples.

\section{Product temperature}

Marinating meat chemically binds water within the meat muscle and in the tissue matrix (Smith and Acton, 2001). The change in the state of free water in the product, due to its interaction with different biochemical constituents in the meat, may have caused the meat products to absorb the $2.5 \mu \mathrm{m}$ peak infrared radiation from the SW infrared heater more readily at the point where samples had been marinated for $24 \mathrm{~h}$. Similarly, the $3.5 \mu \mathrm{m}$ peak infrared radiation from the LW infrared heater may have been absorbed more readily at the point where the samples had been marinated for $12 \mathrm{~h}$; hence, the occurrence of the maximum sample temperature at this marinating duration. The interaction of solutes (ions, organic monomers, etc.) with water molecules affects the absorption maxima of infrared radiation, resulting in a shift of these maxima toward higher or lower wavelengths depending on the hydration potential of the food and the solutes present (Büning-Pfaue, 2003).

Lin et al. (2009) dried apple slices of 5, 9 and $13 \mathrm{~mm}$ thickness and observed that the thinner samples heated up faster than the thicker ones. They attributed the high temperature of thinner samples to the reported $18 \mathrm{~mm}$ maximum depth

Table 2. The most probable number values established per $\mathrm{g}$ of biltong spice, fresh beef, marinated beef, and biltong for heterotrophic microorganisms and Escherichia coli.

\begin{tabular}{|c|c|c|c|c|}
\hline \multirow[t]{2}{*}{ Material analysed } & \multicolumn{2}{|c|}{ Heterotrophic microorganisms } & \multicolumn{2}{|c|}{ E. coli } \\
\hline & $\log _{10}$ MPN/g & $\begin{array}{l}95 \% \text { confidence interval } \\
\text { (lower/upper limit) }\end{array}$ & $\log _{10} \mathrm{MPN} / \mathrm{g}$ & $\begin{array}{l}\text { 95\% confidence interval } \\
\text { (lower/upper limit) }\end{array}$ \\
\hline Sliced fresh beef & 5.11 & $4.66 / 5.57$ & 1.36 & $0.89 / 1.83$ \\
\hline Biltong spice & 4.15 & $3.75 / 4.55$ & nd & - \\
\hline $6 \mathrm{~h}$ marinated beef slices & 4.11 & $3.66 / 4.57$ & 1.11 & $0.65 / 1.56$ \\
\hline $12 \mathrm{~h}$ marinated beef slices & 3.14 & $2.74 / 3.54$ & 1.11 & $0.65 / 1.56$ \\
\hline $24 \mathrm{~h}$ marinated beef slices & 3.23 & $2.81 / 3.64$ & 1.11 & $0.65 / 1.56$ \\
\hline Convective dried biltong & 3.89 & $3.40 / 4.39$ & 0.85 & $0.39 / 1.39$ \\
\hline LW infrared dried biltong & 3.42 & $3.10 / 3.80$ & 0.65 & $0.04 / 1.26$ \\
\hline SW infrared dried biltong & 2.89 & $2.40 / 3.39$ & nd & - \\
\hline
\end{tabular}

E. coli, Escherichia coli; MPN, most probable number; nd, non-detectable (i.e., below the detection limit); LW, long wavelength; SW, short wavelength.

Table 3. Microbiological quality criteria for different meat products.

\begin{tabular}{|c|c|c|c|}
\hline Product & Microbiological quality parameter & Satisfactory/acceptable or not exceeding (CFU per g & References \\
\hline Fresh/raw beef & $\begin{array}{l}\text { Total viable count } \\
\text { E. coli } \\
\text { E. coli }\end{array}$ & $\begin{array}{l}10^{5} / 10^{6} \\
10^{2} / 10^{3} \\
10^{2} / 10^{3}\end{array}$ & $\begin{array}{c}\text { MSC (2002) } \\
\text { MSC (2002) } \\
\text { DGHM (2012) }\end{array}$ \\
\hline Minced meat & $\begin{array}{c}\text { Aerobic colony count } \\
\text { Aerobic colony count } \\
\text { E. coli } \\
\text { E. coli }\end{array}$ & $\begin{array}{c}5 \times 10^{6} / \mathrm{ns} \\
5 \times 10^{5} / 5 \times 10^{6} \\
10^{2} / 10^{3} \\
50 / 5 \times 10^{2}\end{array}$ & $\begin{array}{c}\text { DGHM (2012) } \\
\text { Eurpean Commission (2007) } \\
\text { DGHM (2012) } \\
\text { Eurpean Commission (2007) }\end{array}$ \\
\hline Preserved meat/RTE food & $\begin{array}{c}\text { Aerobic colony count } \\
\text { E. coli }\end{array}$ & $\begin{array}{l}106 / 10^{7} \\
20 / 10^{2}\end{array}$ & $\begin{array}{l}\text { CFS (2007) } \\
\text { CFS (2007) }\end{array}$ \\
\hline Dried herbs and spices & E. coli & $10^{3} / 10^{4}$ & DGHM (2012) \\
\hline
\end{tabular}

CFU, colony forming unit; E. coli, Escherichia coli; ns, not specified; RTE, ready-to-eat. 
of penetration of infrared energy (Krishnamurthy et al., 2008), with infrared radiation penetrating thinner samples better than thicker samples. It is also known that high moisture content foods absorb far infrared radiation more readily than those with lower moisture content (Afzal et al., 1999), resulting in rapid heating up of these foods. Water present in high moisture foods absorbs infrared radiation more strongly in the near infrared region, with food such as potato having a distinct infrared absorption maximum at $2.5 \mu \mathrm{m}$ (Büning-Pfaue, 2003). The fact that fresh meat is a high moisture food might explain why infrared radiation from the $2.5 \mu \mathrm{m}$ (SW) infrared heater was absorbed more readily, thereby heating up samples to a higher temperature compared to the $3.5 \mu \mathrm{m}$ (LW) system.

\section{Product colour and texture}

The $\mathrm{L}^{*}$ index indicates the lightness or darkness of a food sample in a range from black (0) to white (100). Increasing marinating time increased spice uptake, thus yielding a darker product. Darkening of food samples during drying can be caused by non-enzymatic browning (Maskan, 2001), with the product temperature being the major controlling factor. Higher drying temperatures may have increased the occurrence of non-enzymatic browning as evidenced by the SW infrared heater producing the darkest products. The marinating duration had no significant $(P \geq 0.05)$ effect on the $L^{*}$ values of the dried biltong products. Although the products dried with the SW infrared heater were significantly $(\mathrm{P}<0.05)$ darker than those dried using the convective and LW infrared heater, they were generally acceptable based on average lightness values of commercial biltong (Table 1).

The $\mathrm{a}^{*}$ values, indicating the degree of redness or greenness of a food sample in a range from green (-60) to red (60), were generally higher for the convective air dried samples, than for those dried using infrared heaters for all marinating times. Statistical analysis of $\mathrm{a}^{*}$ values showed that there was no significant $(\mathrm{P} \geq 0.05)$ difference between $\mathrm{a}^{*}$ values of biltong products processed in different drying systems or products marinated to different degrees.

The $b^{*}$ values, indicating the degree of yellowness or blueness of a food sample in a range from blue (-60) to yellow (60), were generally higher for samples dried using convective air drying than for those dried using the LW and SW infrared heaters for all marinating times. However, significant $(\mathrm{P}<0.05)$ differences between the $\mathrm{b}^{*}$ values of biltong treated to different marinating levels were not evident.

Texture profile analysis (TPA) mimics the sensation perceived in a human mouth when a food sample is chewed, usually in two successive bites. Increasing marinating time increas- es salt and spice uptake in marinated samples, which can increase dried meat product hardness due to increased protein binding and cross-linking of myofibrils during drying (Thiagarajan et al., 2006). The TPA values were generally higher for samples created with convective air-drying compared to those of samples dried using the two infrared heaters. The TPA values for biltong slices dried with the $2.5 \mu \mathrm{m}$ infrared heater were the lowest of the three drying systems tested, indicating that tenderness increased at higher drying temperature (Martinez et al., 2004). The high drying temperatures and rates experienced for samples dried using infrared heaters, may have brought about proteolytic reactions causing structural weakening and loosening of myofibrils (Tornberg, 1996). In general, samples dried using infrared systems were comparable to those dried using the convective system from a meat quality perspective. They also exhibited a higher degree of tenderness, an attribute desirable to biltong consumers.

\section{Microbiological quality}

Dried RTE meat products should have an acceptable microbial load to guarantee that they are safe for consumption by matching established hygiene requirements and have a proper shelf life. The analysis of the impact of the drying procedure on the microbial burden demonstrated an increasing reduction of the MPN per $\mathrm{g}$ of material analysed as the drying temperature of the product increased; which is expected on microbiological grounds. Using the SW infrared heater caused a reduction in the $\log _{10}$ MPN/g from 5.11 for the fresh meat to 2.89 for the biltong produced, thereby meeting the quality criteria for preserved meat/RTE food of $10^{6}(\mathrm{~m})$ and $10^{7} \mathrm{CFU} / \mathrm{g}(\mathrm{M})$ recommended by the Center for Food Safety (CFS, 2007). This reduction of the microbial load compares favourably to the conventional drying procedure, which only achieved a reduction from an initial $\log _{10}$ MPN/g of 5.11 for the fresh meet to 3.89. Thus, the use of the SW infrared heater enabled an overall $\log _{10} \mathrm{MPN} / \mathrm{g}$ reduction for samples of 2.22 compared to 1.22 when using the conventional drying.

MPN values determined in food samples using general-purpose media indicate the number of viable microorganisms present therein that can grow and multiply. According to the manufacturer, the spice mixture used was gamma irradiated. The MPN value for the biltong spice sample (4.15 $\left.\log _{10} \mathrm{MPN} / \mathrm{g}\right)$ suggested that the irradiation dose or time employed was not sufficient to eliminate endospores of Bacillus spp. present in the spice quantitatively. The DGHM (2012) suggested a limit value $M$ for the food pathogen Bacillus cereus of $10^{4}\left(=4 \log _{10}\right)$ CFU per $g$ of dried spices. Bacterial endospores provide a certain degree of protection against physico- chemical factors such as heat and irradiation (Beaman and Gerhardt, 1986). Endospores surviving heat or irradiation treatment can germinate in the MPN medium employed upon inoculation. Random samples from positive MPN tubes spread plated onto nutrient agar followed by macroscopic and microscopic analysis confirmed the presence of endosporeforming presumptive Bacillus spp., which is in line with other studies reporting the presence of Bacillus spp. in treated spices (Little et al., 2003). As this spice was used in the production of biltong and thus potentially served as a source for endospore formers, it might explain why even under SW infrared treatment causing the highest meat temperatures, the $\log _{10}$ MPN per g did not decrease further than 2.89.

Nortjé et al. (2005) showed that commercial biltong products typically have viable microbial counts of between 6-7 $\log _{10} \mathrm{CFU} / \mathrm{g}$. However, a recent study by Petit et al. (2014) demonstrated that biltong samples obtained from retail outlets in South Africa had plate counts of up to $9.7 \log _{10} \mathrm{CFU} / \mathrm{g}$. Therefore, the lower MPN results obtained in this study (Table 2) indicate acceptable microbiological quality, especially for the biltong produced using the SW infrared heater. The overall quality of biltong processed under both the convective and infrared conditions in the present study was therefore satisfactory in terms of the heterotrophic microbial load in comparison with recommended guideline data (Table 3). However, these results do not take into account the potential post-production contamination of biltong occurring when such food material is exposed to poor hygiene conditions as highlighted in a study by Naidoo and Lindsay (2010b).

Although we did not employ a molecular approach to confirm the identity of presumptive $E$. coli isolates, EMB agar is considered as a reliable means to identify $E$. coli (Leininger et al., 2001). The detection of $E$. coli in the raw beef used for biltong production is therefore somewhat concerning, as it was shown by van den Heever (1965) that the use of meat contaminated with Salmonella spp. led to biltong with viable Salmonella spp. present for up to twelve days. This indicates that the conventional process is not able to eliminate potential pathogens carried through from contaminated meat quantitatively. In addition to using materials of proper hygiene quality to avoid carry through of faecal contamination via the processing, the high temperature regime established using the SW infrared heater would be able to eliminate $E$. coli effectively if present, as temperatures that exceed $70^{\circ} \mathrm{C}$ are known to eliminate this microorganism (Dierschke $e t$ al., 2010). These results demonstrate that the SW heater employed in the drying process of biltong production sufficiently controlled microbial growth in the meat and reduced the 
microbial burden. However, using the LW infrared heater might not be an appropriate choice, as it did not reach $70^{\circ} \mathrm{C}$ (Figure 2B), which might explain the presence of low levels of $E$. coli at the end of the drying process ( $<50$ MPN/g). The same applies to samples that were dried using the convective air-drying system mimicking conventional ambient drying conditions working at about $25^{\circ} \mathrm{C}$ (the convective air dryer set-point temperature), which is not sufficient to inactivate bacteria such as $E$. coli when present. The product temperature of samples dried using the SW infrared heater exceeded $70^{\circ} \mathrm{C}$ (Figure 2B), explaining why the SW infrared heater was able to achieve the highest reduction in the viable heterotrophic microbial burden. The SW infrared dried biltong samples met microbiological quality criteria suggested by international bodies (Table 3 ) at the time of analysis.

\section{Conclusions}

This study demonstrated that infrared heating is a potential alternative to the traditional convective air-drying to produce biltong. The infrared heaters produced biltong with lower microbial loads compared to the convective drying system. Indeed, biltong produced using the SW infrared heater had the lowest microbiological burden, showed no presumptive $E$. coli and matched consumers' expectations regarding colour and tenderness.

\section{References}

Afzal TM, Abe T, Hikida Y, 1999. Energy and quality aspects during combined FIR-convection drying of barley. J Food Eng 42:17782.

AMSA, 2012. AMSA meat color measurement guidelines. 2nd ed. American Meat Science Association ed., Champaign, IL, USA.

AOAC, 2000. AOAC official method 950.46 for determination of moisture in meat. 17th ed. Association of Official Agricultural Chemists ed., Rockville, MD, USA.

Attwell E, 2003. Biltong wakes up. S Afr Food Rev 30:11-3.

Beaman TC, Gerhardt P, 1986. Heat resistance of bacterial spores correlated with protoplast dehydration, mineralization, and thermal adaptation. Appl Environ Microb 52:1242-6.

Bokkenheuser V, 1963. Hygienic evaluation of biltong. S Afr Med J 37:619-21.

Botes HJW, 1966. Biltong induced S. Enteritidis var. Typhimurium food poisoning: a case report. J S Afr Vet Assoc 37:173-4.
Büning-Pfaue H, 2003. Analysis of water in food by near infrared spectroscopy. Food Chem 82:107-15.

Campbell-Platt G, 1995. Fermented meats. A world perspective. In: Prasad Paras N, ed. Frontiers of polymers and advanced materials. Springer, New York, NY, USA, pp 3952.

CFS, 2007. Microbiological guidelines for ready-to-eat food. Food and Environmental Hygiene Department, Center for Food Safety ed., Hong Kong.

Dave D, Ghaly AE, 2011. Meat spoilage mechanisms and preservation techniques: a critical review. Am J Agr Biol Sci 6:486-510.

DGHM, 2012. Mikrobiologische Richt- und Warnwerte zur Beurteilung von Lebensmitteln. Deutsche Gesellschaft für Hygiene und Mikrobiologie ed., Hannover, Germany.

Dierschke S, Ingham SC, Ingham BH, 2010. Destruction of Escherichia coli 0157:H7, Salmonella, Listeria monocytogenes, and Staphylococcus aureus achieved during manufacture of whole-muscle beef Jerky in home-style dehydrators. J Food Protect 73:2034-42.

European Commission, 2007. Commission Regulation of 5 December 2007 amending Regulation (EC) No. 2073/2005 on microbiological criteria for foodstuffs, 1441/2007/EC. In: Official Journal, L322/12-L322/23, 7/12/2007.

Garthright WE, Blodgett RJ, 2003. FDA's preferred MPN methods for standard, large or unusual tests, with a spreadsheet. Food Microbiol 20:439-45.

Hamanaka D, Uchino T, Furuse N, Han W, Tanaka S, 2006. Effect of the wavelength of infrared heaters on the inactivation of bacterial spores at various water activities. Int J Food Microbiol 108:281-5.

Health Canada, 2002. MFHPB-19. Enumeration of coliforms, faecal coliforms and of E. coli in foods using the MPN method. Health Canada, Ottawa, Canada.

Heinz G, García de Siles J, Igene J, 1990. Manual on simple methods of meat preservation. FA0, Rome, Italy.

Heinz G, Hautzinger P, 2010. Meat processing technology for small- medium-scale producers. FAO, Bangkok, Thailand.

Krishnamurthy K, Khurana HK, Soojin J, Irudayaraj J, Demirci A, 2008. Infrared heating in food processing: an overview. Compr Rev Food Sci Food Safety 7:2-13.

Leininger DJ, Robertson JR, Elvinger F, 2001. Use of eosin methylene blue agar to differentiate Escherichia coli from other gramnegative mastitis pathogens. J Vet Diagn Invest 13:273-5.

Lin YL, Li SJ, Zhu Y, Bingol G, Pan Z, McHugh TH, 2009. Heat and mass transfer modeling of apple slices under simultaneous infrared dry-blanching and dehydration process. Dry Technol 27:1051-9.

Little CL, Omotoye R, Mitchell RT, 2003. The microbiological quality of ready-to-eat foods with added spices. Int $\mathrm{J}$ Environ Health Res 13:31-42.

Martinez 0, Salmerón J, Guillén MD, Casas C, 2004. Texture profile analysis of meat products treated with commercial liquid smoke flavourings. Food Control 15:45761.

Maskan M, 2001. Kinetics of colour change of kiwi fruits during hot air and microwave drying. J Food Eng 48:169-75.

MSC, 2002. Microbiological testing for process monitoring in the meat industry. Guidelines. Meat Standards Committee ed., Murarrie, Australia.

Naidoo K, Lindsay D, 2010a. Pathogens associated with biltong product and their in vitro survival of hurdles used during production. Food Prot Trends 15:41-50.

Naidoo K, Lindsay D, 2010b. Potential crosscontamination of the ready-to-eat dried meat product, biltong. Brit Food J 112:35063.

Norman G, Corte 0, 1985. Dried salted meats: charque and carne-de-sol. FA0, Rome, Italy.

Nortjé K, Buys EM, Minnaar A, 2005. Effect of $\gamma$-irradiation on the sensory quality of moist beef biltong. Meat Sci 71:603-11.

Osterhoff D, Leistner L, 1984. South African biltong-another close look. J S Afr Vet Assoc 55:201-2.

Petit T, Caro Y, Petit AS, Santchurn SJ, Collignan A, 2014. Physicochemical and microbiological characteristics of biltong, a traditional salted dried meat of South Africa. Meat Sci 96:1313-7.

Reij M, den Aantrekker E, 2004. Recontamination as a source of pathogens in processed foods. Int $\mathrm{J}$ Food Microbiol 91:1-11.

Sams AR, 2000. Poultry meat processing. CRC Press, Boca Raton, FL, USA.

Smith DP, Acton JC, 2001. Marination, cooking, and curing of poultry products. CRC Press, Boca Raton, FL, USA.

Thiagarajan IV, Meda V, Panigrahi S, Shand P, 2006. Thin-layer drying characteristics of beef jerky. American Society of Agricultural and Biological Engineers, St. Joseph, MI, USA.

Tornberg E, 1996. Biophysical aspects of meat tenderness. Meat Sci 43(Suppl.1):175-91.

Van den Heever LW, 1965. The viability of salmonellae and bovine cysticerci in biltong. S Afr Med J 39:14-6.

Yusop SM, 0'Sullivan MG, Kerry JF, Kerry JP, 2010. Effect of marinating time and low $\mathrm{pH}$ on marinade performance and sensory acceptability of poultry meat. Meat Sci 85:657-63. 